\title{
An Archaeology of French Critical History
}

\author{
Quinn Lester
}

Pomona College, Class of 2013

At first glance a historical trajectory that includes Jean-Jacques Rousseau, Alexis de Tocqueville, and Michel Foucault would seem an odd and contradictory one, with Rousseau and Tocqueville's Enlightenment or liberal politics clashing with Foucault's radical critiques of history and subjectivity. However, such contradictions would only arise from a superficial reading. The archive of these three men's writings reveal similar concerns with overly progressive notions of history and the unquestioned assumptions of the historical subject. These concerns reveal themselves in their different methodological approaches to the archive of history, approaches that emphasize the complexities of material history and a need to critically question dominant paradigms of a progressive history that has taken root since the Enlightenment. When their methodologies are read together Rousseau, Tocqueville, and Foucault reveal themselves to be part of the same critical tradition, one that questions the limits of history and opens up new possibilities for historical research. In this paper I will first outline Foucault's methodology of archaeological research, and then read Rousseau and Tocqueville through a Foucauldian lens to show how they are concerned with the same kinds of questions and, all together, produce a startling critique of Enlightenment progress.

The theory of history that Michel Foucault outlines in The Archeology of Knowledge is an ambitious attempt to create a historical methodology that opposes all those general histories that "draws all phenomenon around a single center," (Foucault 10) whether that be Hegel's worldspirit, Marx's dialectical materialism, or the Enlightenment's view of liberal humanism. Foucault thinks that such histories of continuity obscure the material complexity of events, creating neat narratives from inherently chaotic structures. The purpose of such continuous histories is to serve as the "privileged shelter for the sovereignty of consciousness," (12) that is to say they maintain "man" as a historical subject who makes his own conscious decisions and ultimately will be the victor of history. History becomes the field upon which the complete subject, always present to himself, acts. Foucault's theory of history, instead, is made up of a series of autonomous discourses, themselves separated from each other by irreparable discontinuities. Instead of grounding a subject who will speak history, these discourses both constitute and work through the subject, ending any notion of a sovereign subjectivity. Attacking a whole field of historical research is not simple and Foucault's methodology opens up a new series of questions: what exactly is discourse, how is it formed, and how is it connected to other discourses and the subject. 
Foucault's theory of discourse is not purely a form of critical history, though it can often be deployed for critical methods and research. More traditional critiques, such as Althusser's theory of ideology, posit that there is a true history that is later covered up by a false tradition or false consciousness, and historical research is just a matter of discovering what is hidden underneath. This is not the case for discourse, as there is no true history it refers to or covers up. Discourse cannot "be referred to the distant presence of the origin," (Foucault 25) only treated at the moment of its irruption and analyzed on its own terms, without referring to any abstract origin. As Foucault puts it, the question of discourse is "how is it that one particular statement appeared rather than another?" (27) The origin of a discourse does not relate to an ideal but to its own creation, the discursive formation that is the regularity "between a number of statements, such a system of dispersion, whenever, between objects, types of statement, concepts, or thematic choices" (38). The exact conditions under which these various elements are brought together are the rules of formation, which are unique to every particular discourse and determine why one statement is allowed over and against another.

Central aspects of a discursive formation are the objects that discourse forms, the subject who discourse acts through, and the discourse's field of operations. A key part of a discursive formation is the relation of the discourse as a whole to the particular object it brings into focus and works on or through. Foucault emphasizes that objects should not be seen as the "consequences of a discovery," (Foucault 43) unearthed from within the discourse, but immanent to the foundation of the discourse itself and not prior to it. The object "exists under the positive conditions of a complex group of relations" (45) within discourse. If there are objects then the next question is "who is speaking" (50) about them, from what positions, with what authority. The subject who speaks the authority of a discourse cannot be just anyone, but a particular subject formed by the rules of the discourse he is speaking and from the appropriate site of discourse, such as the medical doctor writing a hospital report. The subject then is not "the pure founding authority of rationality" or the "empirical function of synthesis," (54) but that point in a discursive formation through which discourse comes to act upon the object. Thus does discourse affect the "dispersion of the subject and his discontinuity," (55) fundamentally disrupting any notion of history that attempts to define man as a complete subject with control over his own history. At this point the theory of discourse can begin to sound rather sinister, in both its disruption of continuity and subject. Yet Foucault makes clear that no discourse is total but is "essentially incomplete" (67). A discourse covers a limited field of operations due to the rules of its own formation and thus can be contested from within, revealing the other statements that the particular rules of the discourse do not allow to be spoken.

The problem that Foucault encounters in his methodology is that what exactly forms discourse is rather vague and ultimately hinders his intended goals. As an attempted solution Foucault comes to identify the statement as the component parts of discourse, a "function that cuts across a domain of structures and possible unities" (87). The historical analysis of statements to determine their conditions of being is the archeology that takes place in what Foucault calls the archive, the "systems that establish statements as events...and things" (Foucault 128). The 
particular archive of statements is unique to every particular discourse and in its analysis is found "the general system of the formation and transformation of statements," (130) the very rules of conditions that Foucault wants to establish as the proper horizon of historical analysis which gives statements meaning. It is this form of historical analysis that Foucault calls archaeology, the analysis of "discourses as practices specified in the element of the archive" (131). For some the use of the term archaeology may still imply a certain level of depth, a geological looking underneath of history, yet Foucault tries to be clear that archeology refers to the "general theme" of an analysis which attempts to describe discourse at "the level of its existence" (131). Yet there is still a level of ambiguity in Foucault's methodology, in the exact relation between discourses and statements and the role of archaeological analysis. There is the danger that Foucault may be replacing a teleological view of history with a "history of archives," where the role of research will be to look for lost archives instead of the "true history." This would be a mere reversal of terms instead of a truly discontinuous opening of history.

Even in its ambiguities Foucault's methodology opens up a critical path into history, one that allows the researcher to look again at the past, go into the archive, and write new histories of the present. Yet Foucault should not be seen as a singular aberration but as one figure in a history of critical thinking, of which Jean-Jacques Rousseau and Alexis de Tocqueville are a part. With Foucault's methodology in mind it is possible to see in Rousseau and Tocqueville's work a critical method already at play, to discover the post-modern forms of their histories. In Rousseau's Second Discourse this takes the form of his use of a critical history to critique such given terms as nature, reason, and progress, while Tocqueville's study of the Old Regime and the French Revolution sheds more light on the problems of forming a non-progressive critical history.

In the Second Discourse Rousseau sets himself the task of discovering the original causes of human inequality. He says that the process to discover the root of inequality must begin in "knowing men themselves," (Rousseau 91) or man in his natural state free from society when he was equal. So from the beginning Rousseau's plan appears to be to create a certain duality of nature/equality versus society/inequality. If natural man was free then the simplest thing to do is to discover why he was free and how modern society could form itself better to reflect this natural state. The problem with this plan is that from the very beginning, in the preface to the Second Discourse, Rousseau says that natural man is a state "which no longer exists, which perhaps never existed, and which probably never will exist" (93) The radical nature of this statement should not be underestimated. Much of the Enlightenment project in political theory, as exemplified by John Locke, was based on the idea that there is a natural state of human affairs, this state is more equal or free than modern society, and thus modern society could be changed with this natural state as the model. Rousseau says instead that there is no natural man and there probably never has been to base a political order on.

Rousseau also thinks that the idea of natural man is as much an invention as society itself, that it exists as a discursive object in Foucault's terms. Natural law is the set of "rules on which, for common utility, it would be appropriate that men agree among themselves" (Rousseau 95). This natural law is not discovered but instead invented by writers and philosophers who want a 
more solid basis for their theories. In a Foucauldian sense, natural man is not a primordial state that Enlightenment philosophers discovered through their reason, but an object that came into being at the same time as Enlightenment discourse, both working to solidify the other. Even Rousseau recognizes this and thus calls his work a "hypothetical history of governments," (97) the invention of his own thought, meant purely to be an "instructive lesson for man in all aspects." The question then is, if Rousseau recognizes the artificial nature of natural man as a rhetorical device, why does he still use it in his own work? Rousseau does not clarify this problem for himself. He says that the purpose of his inquiry is still to discover the moment when "nature was subjected to law," (102) or when social inequality triumphed over natural equality. Even if Rousseau's history is not one of "historical truths" (103) it can still be used to "clarify the nature of things." So Rousseau admits that, when it comes to the origins of natural man, none may be found, yet this does not stop natural man per se as existing, perhaps beneath the veneer of society. The complex answer is that even if Rousseau thinks natural man does not exist, as a literary device and discursive object it is still useful as a base, if a paradoxical one, for his argument, as it represents a form of truth that the rest of his ideas can circle around.

The other paradoxical aspect about Rousseau in the Second Discourse is his denigration of the very reason he is using in his philosophical quest. He writes that the "state of reflection is a state contrary to nature" (Rousseau 110) and that whoever would engage in the philosophical life is a "depraved animal." This creates a problem when what Rousseau is doing is exactly the kind of reflection that is contrary to nature. Rousseau sees the origin of reason in the "desire to have pleasure," (116) for it is only the desire for some kind of pleasurable state that would necessitate the "trouble of reason." Reason, then, is not the firm ground upon which knowledge can be built, but a tool for the attainment of pleasure, yet even to begin reasoning is to give up some of the pleasure of the natural state. Rousseau also attacks the prominent Enlightenment idea of natural man as the original philosopher "skillful in the art of thinking" (119). Rousseau writes that in the state of natural man there is no community in which to discover truth and thus no use for reason "which would perish with the individual who would have invented it" (119). Reason is only one of the things natural man gains as he enters a civilized state and is a sign of his fall from nature, not of a return to nature. Again, this could be read as a particularly radical critique, for not only is reason a lesser order of knowing than pleasure or needs, also reason does not reveal natural order at all and cannot get us back to that order either. "Nature" is still a false construct of a reason that desires a solid base of its own thinking.

Having laid out his "hypothetical" history of natural man Rousseau moves in the second half of the discourse to tell how civil society was founded on the basis of property, as he attempts "to assemble from a single point of view this slow succession of events and knowledge in their most natural order," (Rousseau 142) an order that is already suspect. This "history" begins with the different kinds of climate necessitating people to come together briefly for survival, groupings that eventually formed families. Slowly groups are formed, comparison of qualities between people leads to jealousy and greed, and eventually the beginnings of social inequality happen when private property forms and is set into law. This history covers, as Rousseau writes, 
"multitudes of centuries like a flash," (146) an ironic recognition that this history is no more truthful than natural man. Instead, Rousseau uses this history to critique the idea of Enlightenment progress. Rousseau writes that progress is a "fatal accident, which for the common good ought never to have happened" (151). He critiques an Enlightenment progress that is only "in appearance" the history of the "perfection of the individual," of the culmination of the individuals' freedom, and is instead, in material reality, the "decrepitude of the species" (151). The establishment of propertied inequality in politics and law was the moment when people "ran to meet their chains thinking they secured their freedom," (159) a moment that progressive history covers over in its collusion with the dominant powers and ideas that maintain the very social inequality Rousseau critiques.

The Second Discourse culminates as a radical critique of progressive history that builds on Rousseau's earlier critiques of "nature" and reason. Rousseau shows that natural man does not exist and thus no social order can be based on what is considered natural, but also that reason, as a tool of the intellect, is not infallible and due to its own limitations cannot reveal the reality of things either. Absent of this base there is nothing for a progressive history of freedom to build on, and thus Rousseau reveals the radical contingency of history, a formulation of complex events that is similar to Foucault's conception of a history of discontinuities. Yet the paradox of Rousseau is that he uses a reasoned progressive history of natural man in order to critique all these categories. A close reading of certain statements at their surface level reveals an ambiguity in the text around this very issue, as Rousseau posits a "hypothetical" history that is meant to reveal things as they are "in nature." Rousseau then is not an early Foucauldian, despite similarities in his analysis of history and nature as contingent creations of thought, and will even step back in later works from the radical qualities of his work in the Second Discourse. Still Rousseau represents an opening in the history of Western thought, the birth of a paradoxical thinking that will attempt to critique what is within the limits of the possible, and at its best moments reveal the limit of history itself.

Tocqueville continues, in The Old Regime and the French Revolution, this critique of a progressive or "true" history, yet as much as Rousseau or Foucault falls into the problem of how to tell a non-teleological history. Tocqueville says that his aim is to find the French Revolution's "true significance, its real nature," (Tocqueville 4) something that apparently had not been done before him. The question then is why have others not gotten the history of the revolution right and why Tocqueville thinks he is correct. The first answer is that "when great revolutions are successful their causes cease to exist" and thus they become "incomprehensible" (5). A Foucauldian way to put it is that the French Revolution was successful in establishing a new historical discourse to which any event could be referred, and Tocqueville's intent is to investigate what other histories had to be concealed for this dominant narrative of the French Revolution to take hold. The question of why Tocqueville thought he was telling a more accurate history is more complicated. Tocqueville often writes using metaphors of depth when describing his methodology. He says such things as he looks "more deeply into the matter" (11) or "the more deeply [he] went into the subject" (15). It could be said that Tocqueville is acting in a very 
non-Foucauldian manner. For him, in the study of history there is a truth and it is a matter of studying things deeply enough, to discover underneath the detritus of ideologies and personal interests, to find what this true history is. Yet Tocqueville's history is unusual in certain respects from what is often read as more conventional history. There is a kind of progress but it is not a singular one; instead much of his history of the French Revolution is actually separate histories, of different trends that make the Revolution an "inevitable outcome of a long period of gestation, the abrupt and violent conclusion of a process in which six generations had played an intermittent part" (20). Investigating a couple of these trends more closely reveals Tocqueville's exact methodology in practice.

One of the central myths Tocqueville tackles is the idea that before the Revolution the aristocracy had absolute control and all the peasants lived in servitude, only to finally find their freedom in the Revolution. Tocqueville wants to show how Pre-Revolution France was in fact a complex system of competing privileges and freedoms, and though in certain aspects freedom was restrained the power of the government was "far from having broken the spirit of the individual Frenchman" (Tocqueville 108). How does Tocqueville know this? According him it's because he reads the aristocrats' "cahiers [list of grievances] presented to the Estates-General," (110) in which he sees the evidence of a freedom of speech and public standing that lends support to the idea that the aristocracy felt themselves to be equal to the King and his government. The Toquevillian method is a relentless reading of documents, a scouring of the archive, to see what was actually being said. Thus in his readings of court proceedings Tocqueville can find evidence of a court system that, though compromised when it came to holding government officials accountable, could still serve "sometimes as a safeguard of the freedom of the nation" (116). What Tocqueville actually finds in the archive is evidence of "a curiously ill-adjusted, intermittent freedom, always restricted by class distinctions and tied up with immunities and privileges," (119) yet still strong enough to defy a rapidly encroaching central authority. When it came to the situation of peasants Tocqueville discovers a similar situation, where a peasant "enjoyed civil liberty and had land of his own" (120) and yet when compared to an aristocrat was not yet his "fellow citizen - a state of affairs unique in history" (121). Paradoxically, the freedom of the peasants from the aristocracy actually may have made their situation worse as "the villages were left entirely to the tender mercies of the central government," (125) who had no interest in the local running of peasant affairs but only for turning them into "a source of revenue."

Tocqueville can say this because he read "a confidential letter addressed to the Intendant by the Controller-General himself" (Tocqueville 125) and had access to documentary evidence, at once mundane and important, in which he often finds the workings of history as expressed through the minute decisions and concerns of local bureaucrats and rulers. When he reads "the great number of police reports contained in the files of the Intendants' offices" (129) Tocqueville finds evidence of peasants resisting conscription and thus support for his idea of a repressive central government instead of a repressive local aristocracy. On the one hand there is an element to Tocqueville's method where he earnestly sees himself as setting the record straight, showing 
what was actually happening by looking at the "petty details" (135) of police reports and public assembly notes that others had ignored. But Tocqueville's methods often seem like the most surface-level reading possibly, not a reading "between the lines" (136) to discover what men were not saying but to see what they were actually saying all along, a Foucauldian surface-level reading. Tocqueville does not assume that his subjects are lying or covering up any private affairs. His work in the archives reveals, instead of a secret history beneath what was actually said, a history that was covered up after the fact with a progressive history that said peasants were slaves and only became free after the Revolution. It is the materiality of what Tocqueville finds, the literalness of what men wrote, that lends credence to his theories and leads to a counter-history that, far from being secret, in certain ways had to have actually been actively repressed.

Another one of the sacred cows Tocqueville aims at, and which may partly explain why the "true" history of the Revolution remains mystified, is the role of the Enlightenment philosophes. Tocqueville does not deny the key role Enlightenment ideas played and in their great diversity he sees them linked to the idea that "simple, elementary rules deriving from the exercise of the human reason and natural" (Tocqueville 139) were necessary to replace the complex system of feudal privileges and obligations. What fascinates and alarms Tocqueville about these philosophes is that none of them had any practical political experience, such was the "total absence of any political freedom" (140). As things were the philosophes "became the leaders of public opinion and played for a while the part which normally, in free countries, falls to the professional politician" (142). In their focus on abstract rules and premises the philosophes actually ended up benefiting a centralized administration that desired the same kind of overhaul as desired by the philosophes. Again Tocqueville can say this because he has "studied the cahiers drawn up by the three Orders before the meeting of the Estates-General-by all three Orders" (142) and finds that the lists of amendments and proposals desired by the Estates-General, inspired by the work of the philosophes, would have led to the complete change of the government.

If there is a mystification of what actually occurred before the Revolution its root may be found in the dominance of the philosophes, who in their desire for a general rule of all created the idea of a general history, a progressive history of slavery to freedom, that reduces all the complexities of actual society, complexities that Tocqueville seeks to recover in the actual documents of that historical archive. Such was the dominance of these literary philosophes that the language of the Revolution, "of natural law and the rights of man," (Tocqueville 147) was actually present in the speech of politicians and citizens before the Revolution and only in hindsight created the idea that this language was revolutionary and new on its own. Tocqueville laments the idea that this love of "general ideas, systems, and high-flown verbiage" (148) is actually essential to the French, forming a "national trait." Tocqueville actually goes to great pains in his research to show how the discourse of the Revolution only came into existence after the Revolution itself and questions any idea of a revolutionary character that was eternal and ahistorical. In his focus on the pure facts Tocqueville does develop a kind of radical historicity, rejecting any notion of the Revolution as the expression of an innate revolutionary spirit or 
progression of Enlightenment ideals. For Tocqueville it is only by looking at the facts themselves that any kind of history even close to what actually happened can be constructed.

One of the dangers of Tocqueville's method is that, even as he attacks a certain progressive notion of the Revolution as the culmination of Enlightenment principles, he adopts a progressive notion of his own. Tocqueville's main thesis is that much of the characteristics that make the Revolution so revolutionary were already inherent in the Old Regime and the Revolution itself was only the dismantling of the last archaic forms of a system that was "a host of institutions which had quite a 'modern' air" (Tocqueville 209) about them. Tocqueville abandons an idea of Enlightenment progression with his own tale of a certain modern progression, which though it does elucidate much more of the actual factors going into the Revolution, still treats the event itself as a "natural, indeed inevitable, outcome" (203). Despite this tension in Tocqueville's analysis there is still a way that he highlights the Revolution as a highly contingent event owing to a vast array of different institutional reforms and changes in public opinion. Tocqueville makes it possible to see how the French Revolution as an historical event was in many ways only invented after the fact and that a surface-level analysis of what was actually said reveals a very different history with its own insights into the development of modernity in France.

The methodologies of Rousseau, Tocqueville, and Foucault all have interesting similarities between them, forming a unique tradition of critical thinking in all its promise and dangers. Each thinker in his own way tries to reveal a radical contingency at the heart of thinking about history. Foucault in his archeology of historical discourses, Rousseau's dissection of natural man, Tocqueville's critique of an Enlightenment history - all three attempt to show how history as conventionally thought about does not address at certain levels the material reality and complexities of events. Yet all three also reveal the difficulties of attempting to think outside of the possibilities of a contemporary event. Rousseau, as much as he critiques nature and reason in one reading, still has to rely on this categories in his ironic history. Tocqueville can attack one progressive history but only to replace it with one of his own making. Foucault's archeology may be the most radical attempt to formulate a non-teleological history, but the ambiguities of the statement and the archive lead to problems of how to effectively pursue such a historical research. Still, the failures of these men's thinking should not be seen as the failure of critical thinking but as intrinsic to the problem of thought itself. In attempting to think outside of history they reveal the limits of historical thought and open up the possibilities for new thinking that may be seized upon at the next historical moment, a tradition that never ends and produces its own unique history with every new thinker who takes up the problem of history.

\section{Works Cited}

Foucault, Michel. The Archaeology of Knowledge. Vintage Books, New York: 1972.

Rousseau, Jean-Jacques. The First and Second Discourses. St. Martin's Press, New York: 1964. Tocqueville, Alexis de. The Old Regime and the French Revolution. Anchor Books, New York: 1955. 